\title{
Path Loss Propagation Model Prediction for GSM Network Planning
}

\author{
Sami A. Mawjoud \\ Electrical Engineering Department \\ University of Mosul \\ Mosul, Iraq
}

\begin{abstract}
This paper deals with the outdoor path loss behavior. The study has been conducted in Mosul city Iraq to fit a suitable propagation model to measured data at $900 \mathrm{MHz}$ and 1800 $\mathrm{MHz}$ in urban and suburban environment. The empirical models dealt which are Hata, Cost-231 Hata, international Telecommunication Union (ITU-R), Ericsson and Stanford University Interm (SUI). Path loss accuracy of the fitting of the empirical models to the measured data is estimated using Root Mean Square (RMS) error.
\end{abstract}

\section{Keywords}

Path Loss Models, Propagation Measurement, GSM Network Planning, $900 \mathrm{MHz}, 1800 \mathrm{MHz}$

\section{INTRODUCTION}

It is of vital importance in network planning is the predication of path loss and hence the coverage area, frequency assignment and interference which are the main concern in mobile network planning. The available empirical formulae cannot be generalized to different environment (urban, suburban, ..etc), in general the suitability of these models differ for different environments. The data collected from measurements are compared with four empirical propagation models at $900 \mathrm{MHz}$ and $1800 \mathrm{MHz}$ in urban and suburban areas in Mosul city. The accuracy of path loss model is estimated by calculating the Root Mean Square (RMS) error between the measured and estimated path loss of the applicable empirical models.

\section{PATH LOSS MODELS}

Radio transmission in mobile communication system often takes place over irregular terrain. A number of propagation models are available to predict path loss over different types of terrain [1][2]. The models dealt with are applicable for GSM bands (900 MHz, $1800 \mathrm{MHz}$ ).

\subsection{Hata Model}

Hata Model [3][4] is an empirical formulation of graphical path loss data provided by Okumura model. The Hata model gives prediction of the median path loss. The standard formula for urban area is

$\mathrm{P}_{\mathrm{L}(\text { urban })}(\mathrm{dB})=69.55+26.16 \log _{10}\left(\mathrm{f}_{\mathrm{c}}\right)-13.82 \log _{10}\left(\mathrm{~h}_{\mathrm{b}}\right)-\mathrm{a}\left(\mathrm{h}_{\mathrm{m}}\right)$ $+\left(44.9-6.55 \log _{10}\left(\mathrm{~h}_{\mathrm{b}}\right)\right) \log _{10}(\mathrm{~d})$

Where $\mathrm{fc}$ is $\mathrm{MHz}$ and for frequency range of $150 \mathrm{MHz}$ to 1500 $\mathrm{MHz}, \mathrm{h}_{\mathrm{b}}$ is the BTS effective transmitter antenna height in meter ranging from $30 \mathrm{~m}$ to $200 \mathrm{~m}, \mathrm{~h}_{\mathrm{m}}$ is the effective mobile receiver antenna height in meter ranging from $1 \mathrm{~m}$ to $10 \mathrm{~m}$.

$\mathrm{d}$ is the distance between Base Station (Bs) and the Mobile Station (Ms) in Kilometers.

$\mathrm{a}\left(\mathrm{h}_{\mathrm{m}}\right)$ is the correction factor for effective Ms antenna height which is a function of the size of the coverage area .

For a small to medium size city, the mobile antenna correction factor is given by :

$$
a\left(h_{m}\right)=\left(1.1 \log _{10}\left(f_{c}\right)-0.7\right) h_{m}-\left(1.56 \log _{10}\left(f_{c}\right)-0.8\right)
$$

To obtain the path loss in suburban area, equation (1) is modified to

$$
\mathrm{P}_{\mathrm{L}(\text { Suburban })}(\mathrm{dB})=\mathrm{PL}_{(\text {urban })}-2\left(\log _{10}(\mathrm{fc} / 28)\right)^{2}-5.4
$$

The predication of Hata model compares very closely with the original Okumura model as long as d exceeds $1 \mathrm{~km}$. This model is suitable for large cell system, but not personal communication systems (PCS) which have cells of the $1 \mathrm{~km}$ radius [2].

\subsection{Cost-231 Hata Model}

The European Cooperative for Scientific and Technical research (EURO-COST) formed the COST-231 working committee to develop an extended version of the Hata model. Cost-231 proposed path loss model is [5][6]

$$
\begin{gathered}
P_{L(\text { urban })}(d B)=46.3+33.9 \log _{10}\left(f_{c}\right)-13.82 \log _{10}\left(h_{b}\right)-a\left(h_{m}\right) \\
+\left(44.9-6.55 \log _{10}\left(h_{b}\right)\right) \log _{10}(d)+C_{m} \ldots(4)
\end{gathered}
$$

Where $\mathrm{a}\left(\mathrm{h}_{\mathrm{m}}\right)$ is defined as.

$$
a\left(h_{m}\right)=\left(1.1 \log _{10}\left(f_{c}\right)-0.7\right) h_{m}-\left(1.56 \log _{10}\left(f_{c}\right)-0.8\right) d B
$$

$\mathrm{C}_{\mathrm{m}}=0$ for median sized cities and suburban areas.

$=3 \mathrm{~dB}$ for metropolitan areas

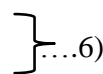

The Cost-231 extension of the Hata model is restricted to the following range of parameters, $\mathrm{f}_{\mathrm{c}}$ is $1500 \mathrm{MHz}$ to $2000 \mathrm{MHz}$, $\mathrm{h}_{\mathrm{b}}$ is $30 \mathrm{~m}$ to $200 \mathrm{~m}, \mathrm{~h}_{\mathrm{m}}$ is $1 \mathrm{~m}$ to $10 \mathrm{~m}$ and $\mathrm{d}$ is $1 \mathrm{~km}$ to $20 \mathrm{~km}$.

\subsection{ITU-R Model}

The ITU-R model is to be used for the outdoor to indoor and pedestrian (microcell) in urban and suburban environment [7][8]. The path loss is given as:

$P_{L}(d B)=40 \log d+30 \log f_{c}+49$

Where: $\mathrm{d}$ is the distance between the base station and the mobile unit in $\mathrm{km}, \mathrm{f}_{\mathrm{c}}$ is the frequency to $2000 \mathrm{MHz}, \mathrm{L}$ in no circumstances to be less than free space loss. The model is for Non-Line of Sight (NLOS) case only and describes worst condition deviation of $10 \mathrm{~dB}$ for outdoor users. 


\subsection{ERICSSON Model}

Model 9999 [9][10] is the Ericsson's implementation of Hata model. In this model parameter is possible according to propagation environment. The path $\operatorname{loss} \mathrm{P}_{\mathrm{L}}$ is given as:

$P_{L}(d B)=a_{0}+a_{1} \log (d)+a_{2} \log \left(h_{b}\right)+a_{3} \log \left(h_{b}\right) \log (d)-3.2$ $\left(\log \left(11.75 h_{m}\right)\right)^{2}+g(f)$

Where $g(f)$ is defined by : $g(f)=44.49 \log (f)-4.78(\log (f))^{2}$

The parameters $a_{0}, a_{1}, a_{2}$ and $a_{3}$ are constants, and can be change for better fitting specific propagation conditions. Default values are $\mathrm{a}_{\mathrm{o}}=36.2, \mathrm{a}_{1}=30.2, \mathrm{a}_{2}=-12$, and $\mathrm{a}_{3}=0.4$.

\subsection{Stanford University Interm (SUI) Model}

The Stanford University Interm (SUI) model [11][12] in developed under the institute of Electrical and Electronic Engineers (IEEE) 802.16 broad band wireless access working group. The model is an extension of the Hata model with correction parameters for frequencies above $1900 \mathrm{MHz}$. The SUI model can be used for base station antenna height of 10 meters to 80 meters, the mobile station antenna height between 2 meters to $8 \mathrm{~km}$. The SUI model is divided into three types of terrain (environments) namely A, B and C. Type A is associated with maximum path loss and is appropriate for hilly terrain with moderate to heavy foliage densities, type $\mathrm{C}$ is associated with minimum path loss and densities. Type B is characterized with characterized with either mostly flat terrain with moderate to heavy tree densities or hilly terrain with light tree densities. The basic path loss equation is given by:

$$
P_{L}(d B)=A+10 \Upsilon \log _{10}\left(d / d_{o}\right)+X_{f}+X_{h}+S
$$

Where: $\mathrm{d}$ is the distance between the base station and the receiving antenna, $d=100 \mathrm{~m}, \mathrm{~S}$ is the lognormal distributed factor that is used to account for the shadow fading due to trees and other clutter and has a value between $8.2 \mathrm{~dB}$ and $10.6 \mathrm{~dB}$. The remaining parameters are defined as:

$$
\begin{aligned}
& \mathrm{A}=20 \log _{10}\left(4 \pi \mathrm{d}_{\mathrm{o}} / \lambda\right) \\
& \mathrm{Y}=\mathrm{a}-\mathrm{bh}_{\mathrm{b}}+\mathrm{c} / \mathrm{h}_{\mathrm{b}}
\end{aligned}
$$

Where the parameter $h_{b}$ is the base station height above ground in meters and between $10 \mathrm{~m}-80 \mathrm{~m}$. The constant used for $\mathrm{a}, \mathrm{b}$ and $\mathrm{c}$ are given in table 1 . The parameters $\mathrm{r}$ in equation (13) is the path loss exponent. For a given terrain type the path loss exponent is determined by $h_{b}$.

Table (1) SUI model numerical values for different terrain categories

\begin{tabular}{|c|c|c|c|}
\hline $\begin{array}{c}\text { Mode } \\
\text { Parameters }\end{array}$ & $\begin{array}{c}\text { Terrain A } \\
\text { (hilly/moderate } \\
\text { to heavy tree } \\
\text { density) }\end{array}$ & $\begin{array}{c}\text { Terrain B } \\
\text { (hilly/light tree } \\
\text { density of flat } \\
\text { / moderate to } \\
\text { heavy tree } \\
\text { density) }\end{array}$ & $\begin{array}{c}\text { Terrain C } \\
\text { (flat/light } \\
\text { tree } \\
\text { density) }\end{array}$ \\
\hline $\mathrm{a}$ & 4.6 & 4.0 & 3.6 \\
\hline $\mathrm{b}\left(\mathrm{m}^{-1}\right)$ & 0.0076 & 0.0065 & 0.005 \\
\hline $\mathrm{c}$ & 12.6 & 17.1 & 20 \\
\hline
\end{tabular}

The correction factor for the operation frequency for the receiver antenna height for the model is:

$$
X_{\mathrm{f}}=6 \log _{10}(\mathrm{f} / 2000)
$$

$\mathrm{X}_{\mathrm{h}}=-10.8 \log _{10}\left(\mathrm{~h}_{\mathrm{r}} / 2000\right) \quad$ for terrain type A and B ....(14)

$X_{h}=-20.0 \log _{10}\left(h_{r} / 2000\right) \quad$ for terrain type $C$

$\mathrm{f}$ is the frequency in $\mathrm{MHz}$ and $\mathrm{h}_{\mathrm{r}}$ is the receiver antenna height above ground in $\mathrm{m}$. The SUI model is used to predict the path loss in all three environments namely urban, suburban and rural. In the present paper SUI model B is chosen compling to the areas under study in Mosul city.

\section{EXPERIMENTAL RESULTS}

The measurements has been carried out in Mosul city areas at $900 \mathrm{MHz}$, different terrains are considered, Faysalya (Urban) and Wana (Suburban). Similarity at $1800 \mathrm{MHz}$, Industrial zone (Urban) and Sinjar (suburban). The base station transmitting sites specifications are shown in table 2 .

Table (2) Specifications of Base Stations Sites

\begin{tabular}{|l|c|c|c|c|}
\hline Site Name & Faysalya & Wana & $\begin{array}{c}\text { Industri } \\
\text { al zone }\end{array}$ & Sinjar \\
\hline Antenna Gain & $17 \mathrm{~dB}$ & $17 \mathrm{~dB}$ & $18 \mathrm{~dB}$ & $18 \mathrm{~dB}$ \\
\hline Antenna Height & $22 \mathrm{~m}$ & $58 \mathrm{~m}$ & $35 \mathrm{~m}$ & $26 \mathrm{~m}$ \\
\hline $\begin{array}{l}\text { Antenna } \\
\text { Downtilt }\end{array}$ & $5.5^{\circ}$ & $5.5^{\circ}$ & $5.5^{\circ}$ & $5.5^{\circ}$ \\
\hline $\begin{array}{l}\text { Frequency } \\
\text { Band }\end{array}$ & $900 \mathrm{MHz}$ & 900 & 1800 & $1800 \mathrm{M}$ \\
& & $\mathrm{MHz}$ & $\mathrm{MHz}$ & $\mathrm{Hz}$ \\
\hline Max Tx Power & $47 \mathrm{dBm}$ & $47 \mathrm{dBm}$ & $45 \mathrm{dBm}$ & $45 \mathrm{dBm}$ \\
\hline
\end{tabular}

\subsection{Method of Measurements}

Measurements of the received power have been executed using a special Sony Ericsson handset. The handset contains a software, memory and a Global Position System (GPS) chipset. When the received power measurement is required, the handset is activated and held by the user either pedestrian or in a car depending on the measurement required. The handset record the received power by time intervals defined by the user e.g five seconds. At each received power measurement, the distance separation from base station transmitter is also received by the GPS chipset in the handset. The information of the received power, distance, frequency and time of measurement is stored in the memory of the handset. After completing the measurement, the handset is then connected to a personal computer (PC) through a Universal Serial Bus (USB) port and the data stored in the memory of the handset is transfer to software in the PC. The Test Mobile System Measurement Unit (TEMS) is special software used for processing and analyzing the collected measurement and can display the measurements on maps stored inside it or download from Internet. To obtain the path loss, the received power is subtracted from the transmitted power of the base station which is known to the cellular operator.

\subsection{Method of Simulation}

In this paper the software used for the simulation of the received power is MATLAB v7.8, the program is written as mfile formed. The complete information of the areas under consideration are entered to the program and stored in the file, information such as transmitter antenna (base station) height, receiver antenna (mobile unit) height, terrain information, operating frequency, etc. When the simulation is run, the mobile starts to move on the same direction of the actual 
mobile measurements path. According to the path loss model used, the path loss of each location is calculated and stored in the program. Four path loss models are used in this study for the $900 \mathrm{MHz}$ frequency and the $1800 \mathrm{MHz}$ frequency, they are Hata model, Cost-231 Hata model, ITU-R model, Ericsson model and SUI model. For each model, the simulation is run for the two frequencies bands $900 \mathrm{MHz}$ and $1800 \mathrm{MHz}$, and for each frequency, two types of terrain, urban and suburban are considered.

\subsection{Root Mean Square Error (RMS Error)}

An efficient method for estimating the accuracy of path loss model is the RMS error, which is the difference in $\mathrm{dB}$ between the measured path loss and estimated path loss [13][14][15].

RMS Error $(\mathrm{dB})=\sqrt{\frac{1}{N} \sum_{\mathrm{i}=1}^{\mathrm{N}}\left(L_{m i}-L_{e i}\right)^{2}}$

Where:

$\mathrm{L}_{\mathrm{mi}}$ is the measured path loss in $\mathrm{dB}, \mathrm{L}_{\mathrm{ei}}$ is the estimated path loss from the model in $\mathrm{dB}$, and Nis the number of total data.

\section{Results and Discussion}

Figures 1 and 2 show the results of path loss estimation using the path loss models of Hata, ITU-R, Ericsson and SUITypeB for two different areas in Mosul city which are Faysalya (urban area) and Wana (suburban area) both measured results are estimated at $900 \mathrm{MHz}$ frequency. Figures 3 and 4 show the at $1800 \mathrm{MHz}$, the areas are Industrial zone (urban) and Singar (suburban) using Cost-231 Hata model, ITU-R, Ericsson and SUI-TypeB. The mean square error of the four graphics is calculated using equation (16) and the results are in figures 3 and table 4 .

Table (3) RMS Error for propagation models

\begin{tabular}{|c|c|c|c|c|c|}
\hline \multirow{2}{*}{$\begin{array}{c}\text { Frequency } \\
(\mathrm{MHz})\end{array}$} & Area & \multicolumn{4}{|c|}{ Models RMS Erorr (dB) } \\
\cline { 3 - 6 } & & Hata & ITU-R & Ericsson & SUI \\
\hline \multirow{3}{*}{$900 \mathrm{MHz}$} & $\begin{array}{c}\text { Faysalya } \\
\text { (urban) }\end{array}$ & 9.8 & 17.3 & 12.6 & 28 \\
\cline { 2 - 6 } & $\begin{array}{c}\text { Wana } \\
\text { (suburban) }\end{array}$ & 8.1 & 31 & 7.4 & 37.1 \\
\hline
\end{tabular}

Table (4) RMS Error for propagation models

\begin{tabular}{|c|c|c|c|c|c|}
\hline \multirow{2}{*}{$\begin{array}{c}\text { Frequency } \\
(\mathrm{MHz})\end{array}$} & Area & \multicolumn{4}{|c|}{ Models RMS Erorr (dB) } \\
\cline { 3 - 6 } & $\begin{array}{c}\text { Cost- } \\
\text { Hata }\end{array}$ & ITU-R & Ericsson & SUI \\
\hline \multirow{2}{*}{1800} & $\begin{array}{c}\text { Industrial } \\
\text { zone(urban) }\end{array}$ & 12.1 & 21.1 & 15.4 & 27.1 \\
\cline { 2 - 6 } $\mathrm{MHz}$ & $\begin{array}{c}\text { Sinjar } \\
\text { (suburban) }\end{array}$ & 17.9 & 17.9 & 19.3 & 25.1 \\
\hline
\end{tabular}

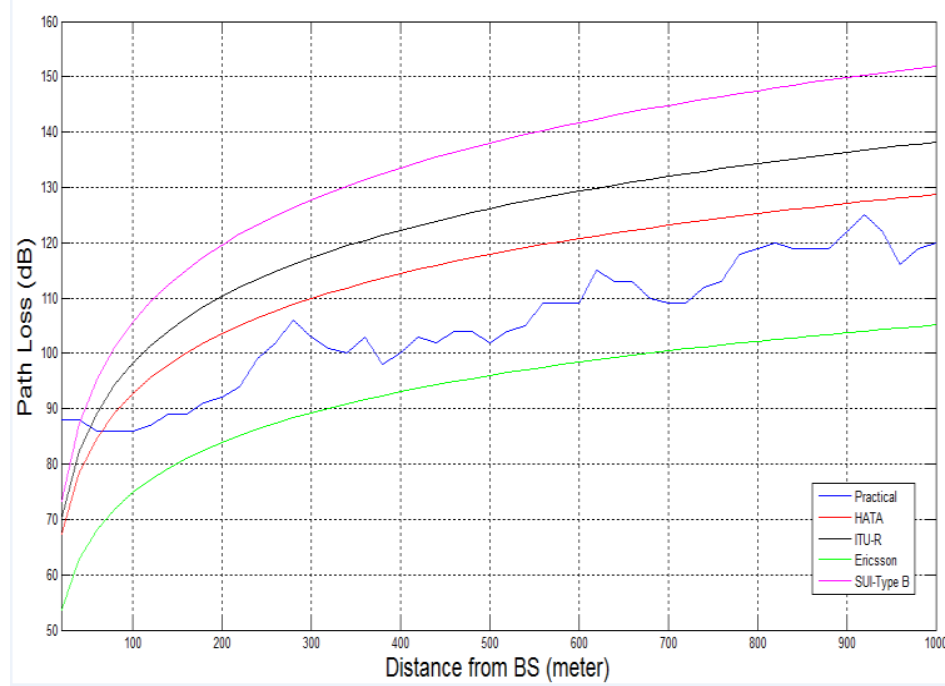

Figure (1): Faysala (urban) at 900MHz

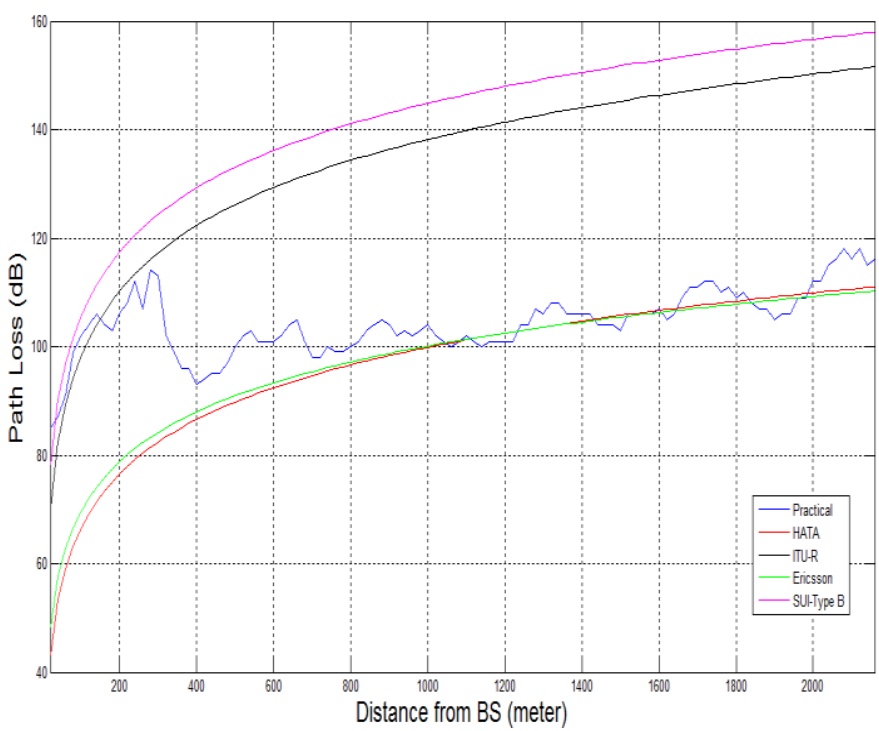

Figure(2): Wana (Suburban) at $900 \mathrm{MHz}$

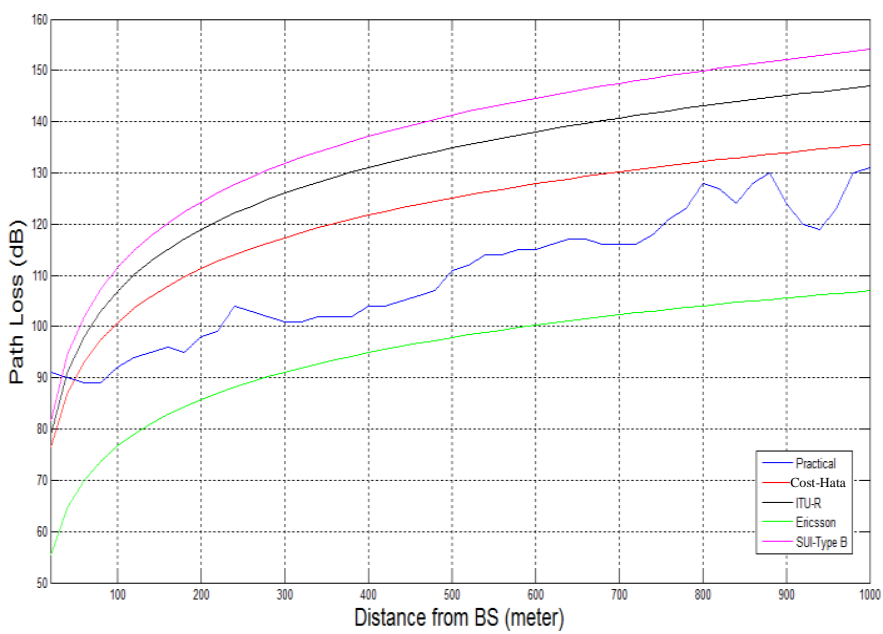

Figure(3): Industrial Zone (urban) at $1800 \mathrm{MHz}$ 


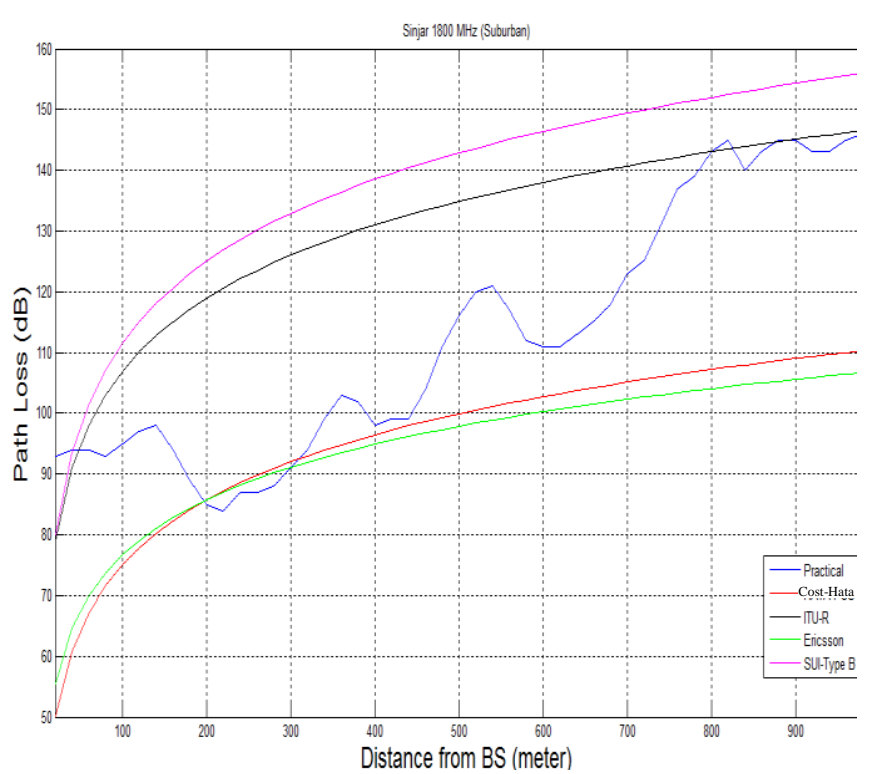

Figure(4): Sinjar (Suburban) at 1800MHz

\section{CONCLUSIONS}

In this paper the applicable path loss models are compared with measured path loss for urban and suburban areas in Mosul city for two frequency bands of $900 \mathrm{MHz}$ and 1800 $\mathrm{MHz}$. At $900 \mathrm{MHz}$ frequency the best fit models for Faysalya (Urban) and Wana (Suburban) is first Hata model and the second is the Ericsson model. For $1800 \mathrm{MHz}$ frequency, the best fit for Industrial zone (Urban) and Sinjar (Suburban) area is the Cost-Hata model.

\section{REFERENCES}

[1] N. Shabbir, M. Saidq, T. Kashif, and R.Ullah, " Comparison of Radio Propagation Models For Long Term Evolution (LTE) Network", International Journal of Next generation networks, Vol. 3, No. 3, September 2011.

[2] S. Ranviers, " Path loss Models", Finland Helsinki University of Technology 2004, Available at http//: www.comlabhut.fi/opetus/333/2004-2005-sides/pathloss-models.pdf.

[3] Hata M., "Empirical Formula For Propagation Loss in Land Mobile Radio Services", IEEE Transaction on Vechicular Technology Vol. 29, No. 3, 1980.
[4] TH. Rappaport, "Wireless Communication Principles and Practice", $2^{\text {ned }}$ Edition, Prentice Hall, India, 2006.

[5] European Cooperation in the Field of Scientific and Technical Research Euro- Cost 231 urban Transmission loss Model for Mobile Radio in the $900 \mathrm{MHz}$ and $1800 \mathrm{MHz}$ Bands. Revision2, The Hague, September 1991

[6] Goldsmith A., " Wireless Communication", USA, Cambridge University Press, 2005.

[7] ITU-R M.1225, " Guide lines for Evaluation of Radio Transmission Technology for IMT-200", 1997.

[8] ITU-R 1546-4, " Method for Point to Area Predication for Terrestrial Services in the Frequency Rang $30 \mathrm{MHz}-$ 300MHz", Geneva, 2009.

[9] N. Shabbir, H. Kashif, " Radio Resource Management in WiMAX", Ms Thesis, Bleking Institute of Technology, Karlskrona Sweden, 2009.

[10] J. Lanovic, S. Rimac, and K. Bejuk, " Comparison of Propagation Models Accuracy for WiMAX on $3.5 \mathrm{GHz}$, IEEE International Conference on Electronics, 2007.

[11] V. Erceg, L. Greenstein, " An Empirical Based Path Loss Model for Wireless Channels in Suburban Environments", IEEE Journal on Selected Areas of Communication", Vol. 17, pp/ 1205-1211, July 1999.

[12] M. Didarul and M. Razaul, " Comparative Study of Path Loss Models of WiMAX at $2.5 \mathrm{GHz}$ Frequency Band.

[13] B. Castro, M. Pinheiro, G. Canalcante, " Comparison Between Known propagation Models Using Least Square Tuning Algorithm on $5.8 \mathrm{GHz}$ in Amazon Region Cities", Journal of Microwaves, Optoelectronics Application, Vol. 10, No. 1, June 2011.

[14] Z. Nadir, I. Aeng, N. Flfadhil, and F. Touati, " Path Loss Determination Using Okumura-Hata Model and Spline Interpolation for Missing Data for Oman", Proceedings of the World Congress on Engineering, Vol. 1,pp.2-4, London UK, July 2008.

[15] K. Diawuo, T. Cemberbatch, " Data Fitting to Propagation Model Using Least Square Algorithm: A Case Study in Ghana", International Journal of Engineering Science, Vol. 2, No. 6, June 2013. 